(D) Check for updates

Cite this: Food Funct., 2018, 9, 4664

\title{
Phenolic profile and in vitro bioactive potential of Saharan Juniperus phoenicea L. and Cotula cinerea (Del) growing in Algeria
}

\author{
Dalila Ghouti, (D) a,b Wahiba Rached, (D) a,c,d Moussaoui Abdallah, (D) e \\ Tânia C. S. P. Pires, (iD a Ricardo C. Calhelha, (iD a Maria José Alves, (D) a \\ Lazzouni Hamadi Abderrahmane, (ID f Lillian Barros (D) *a and Isabel C. F. R. Ferreira (iD *a
}

\begin{abstract}
The aim of this study was to characterize the individual phenolic profile and antioxidant, anti-inflammatory, cytotoxic, and antimicrobial activities of hydroethanolic and infusion extracts prepared from Algerian Saharan Juniperus phoenicea L. and Cotula cinerea (Del). The phenolic profile was determined using a liquid chromatograph coupled to a diode array detector and an electrospray ionization mass spectrometer (LC-DAD-ESI/MS). A total of thirteen and nine individual phenolic compounds were identified in J. phoenicea and C. cinerea, respectively. 3-p-Coumaroylquinic acid, quercetin- and myricetin-O-pentoside were the major compounds present in J. phoenicea; on the other hand, $C$. cinerea presented luteolin-7-O-glucoside, luteolin-O-malonylhexoside, and 5-O-caffeoylquinic acid as the main molecules. In general, all samples exhibited interesting antioxidant activity when compared to the standard Trolox, but J. phoenicea extracts presented the highest bioactivity. Likewise, all the samples exhibited anti-inflammatory activity; thus $\mathrm{J}$. phoenicea hydroethanolic extracts showed the highest potential $\left(88 \pm 8 \mu \mathrm{g} \mathrm{mL}^{-1}\right)$. In addition, their cytotoxicity was evaluated towards a panel of four selected cell lines ( $\mathrm{HeLa}, \mathrm{NCl}-\mathrm{H} 460$, MCF-7 and HepG2), and all the extracts showed cytotoxic effects, with J. phoenicea extracts being the most effective. The in vitro antimicrobial activity of the plant extracts was moderate, Gram-positive bacteria thus being more sensitive than the Gram-negative strains (MIC values between 5 and $20 \mathrm{mg} \mathrm{mL}^{-1}$ ). The present work suggests that $J$. phoenicea and $C$. cinerea are sources of bioactive ingredients with potential use in the food and pharmaceutical industries.
\end{abstract}

Received 12th July 2018 Accepted 14th August 2018

DOI: $10.1039 /$ c8fo01392f

rsc.li/food-function such as terpenoids, alkaloids, and phenolic compounds, like flavonoids, tannins, coumarins and phenolic acids. ${ }^{1}$ These biomolecules are widespread in different plant parts, such as fruits, leaves, and seeds. ${ }^{2}$ Nowadays, there is an increasing interest in the consumption of phytochemicals, like phenolic compounds, due to their important health effects, which are caused by their protective properties against a variety of pathologies mainly related with oxidative stress. ${ }^{3}$ Many authors have reported the beneficial effects of polyphenols and mentioned that they present numerous bioactive properties, such as antibacterial, ${ }^{4,5}$ antiviral, antifungal, ${ }^{6}$ cytotoxic, ${ }^{7}$ and antiinflammatory ${ }^{8,9}$ properties. These properties depend on their specific chemical structures ${ }^{10}$ and much attention has been paid to the extraction and isolation of polyphenols from herbs having the ability to protect food and living systems from peroxidative damage. ${ }^{11}$

In order to search for effective natural bioactive compounds, the current study selected two traditional medicinal plants based on their ethno-pharmacological importance, for 
being applied as pharmaceutical and dietary supplements. Among the medicinal plants, Juniperus phoenicea L. and Cotula cinerea (Del) are Algerian Saharan herbs, harvested from southwest of Algeria and known to possess biological properties. $J$. phoenicea (Cupressaceae) is a small shrub of the Mediterranean basin, mostly distributed in its western part and largely growing in the Algerian mountains. ${ }^{12} \mathrm{~J}$. phoenicea is considered an important medicinal plant that is used in folk medicine, where decoctions and infusions of its leaves are used to treat diarrhea, rheumatism, bronco-pulmonary, diuretic, diabetic and obesity diseases; ${ }^{13,14}$ it is also used in the treatment of hepatotoxicity and nephrotoxicity. ${ }^{15} \mathrm{~A}$ recent study on J. phoenicea growing in Egypt reported that the crude extracts (petroleum ether, chloroform, ethyl acetate, and methanol) showed antiproliferative activity against lung carcinoma (H460), liver tumor (HepG2), and breast carcinoma (MCF7) cell lines. ${ }^{16}$ Moreover, the hydroethanolic extract prepared from Algerian species demonstrated antioxidant activity. ${ }^{17}$ The main bioactive compounds described in Juniperus species are mostly phenolic compounds. ${ }^{18}$ Boulanouar et $a .^{17}$ analyzed these molecules using spectrophotometric methods and concluded that hydroalcoholic extracts of the aerial parts of $J$. phoenicea mainly presented phenolic acids and flavonoids. In addition, the presence of the biflavone, agathisflavone, in hydroalcoholic extracts of J. phoenicea leaves growing in Egypt was also reported. ${ }^{16}$ Four flavonoid derivatives (cupressuflavone, hinokiflavone, hypolaetin-7-O- $\beta$-xylopyranoside and catechin) present in petroleum ether, chloroform, and methanol fractions obtained from the crude ethanol extract of the aerial parts of $J$. phoenicea growing in Saudi Arabia were isolated and detected by Alqasoumi et al. $^{19}$

Cotula cinerea (Del) is a synonym of Brocchia cinerea (Dil.) Vis. (Asteraceae); it is known as a xerophytic herb in Algeria by the name "Guertouffa" or Saharan camomile (English) and is commonly found in the Algerian desert. ${ }^{12}$ It is traditionally used as infusions and decoctions to treat digestive troubles, rheumatoid arthritis, urinary and pulmonary infections, fever, headaches, migraines, coughs, and joint inflammation. ${ }^{20}$ This species has been described to have antioxidant, analgesic, antiseptic, and antimicrobial properties. ${ }^{21-24}$ The main compounds have been isolated from the methanol extracts of Egyptian and Moroccan C. cinerea, and identified as phenolic acids (neochlorogenic acid, chlorogenic acid, cryptochlorogenic acid, and 3,4-dicaffeoylquinic acid) and flavonoids (luteolin-4'-O-glucoside, luteolin-7-O- $\beta$-D-glucoside, luteolin-6hydroxy-7-O- $\beta$-D-glucoside, apigenin-7-O- $\alpha$-rhamnoside, apigenin6-C-arabinosyl-8- $C$-glucoside, isoschaftoside, quercetin-3-O- $\beta$-Dglucoside, and 5,3',4'-trihydroxy 3,6,7-trimethoxyflavone). ${ }^{25,26}$

In this study, the most common form of consumption (infusion) of $J$. phoenicea and C. cinerea (Del) collected in southwest of Algeria was compared with a crude hydroethanolic extract. The extracts of both species were characterized in terms of phenolic composition and bioactive properties, such as antioxidant, cytotoxic, anti-inflammatory, and antimicrobial activities.

\section{Materials and methods}

\subsection{Plant material}

The samples of Juniperus phoenicea L. leaves and Cotula cinerea (Del) aerial parts were collected in southwest of Algeria at EL Bayadh ( $33^{\circ} 05^{\prime} 18^{\prime \prime}$ North; $0^{\circ} 34^{\prime} 52^{\prime \prime}$ East) and Bechar ( $31^{\circ} 01^{\prime}$ $00^{\prime \prime}$ North; $2^{\circ} 44^{\prime} 00^{\prime \prime}$ West), respectively, during the flowering period (May 2015). The plants were identified by Okacha Hasnaoui, Professor at the University of Tlemcen, Algeria. The samples were dried and ground to a fine powder ( 20 mesh) prior to analysis.

\subsection{Extraction procedure}

Hydroethanolic and infusion extracts were prepared from J. phenica leaves and C. cinerea aerial parts. The hydroethanolic extraction $(80 \%$ ethanol, $30 \mathrm{~mL})$ was performed by maceration (150 rpm), with $1 \mathrm{~g}$ of each sample at $25{ }^{\circ} \mathrm{C}$ for $1 \mathrm{~h}$ and then filtered; the residue was re-extracted using the same methodology. Afterwards, the extracts were evaporated in order to remove the ethanol, under reduced pressure (Büchi R-210 rotary evaporator, Flawil, Switzerland). For aqueous extracts, $2 \mathrm{~g}$ of plant material was infused with boiling distilled water $(200 \mathrm{~mL})$ for $15 \mathrm{~min}$ and then filtered. Both extracts were previously frozen before lyophilizing (FreeZone 4.5, Labconco, Kansas City, MO, USA), in order to obtain a dry extract.

The lyophilized hydroethanolic and infusion extracts were dissolved in ethanol/water $(80: 20, \mathrm{v} / \mathrm{v})$ and water, respectively, to obtain a stock solution of $10 \mathrm{mg} \mathrm{mL}^{-1}$ for the antioxidant activity assays: $5 \mathrm{mg} \mathrm{mL}^{-1}$ for the phenolic compound characterization; $20 \mathrm{mg} \mathrm{mL}{ }^{-1}$ in culture medium for the antimicrobial assays; finally, $8 \mathrm{mg} \mathrm{mL} \mathrm{m}^{-1}$ in water for anti-inflammatory and cytotoxicity tests. In the bioactivity evaluation assays, the stock solutions were further diluted and tested.

\subsection{Phenolic compound characterization}

LC-DAD-ESI/MSn (Dionex Ultimate 3000 UPLC, Thermo Scientific, San Jose, CA, USA) was used for phenolic compound characterization (identification and quantification), as previously detailed by Bessada et $a .^{27}$ The detection was preformed using a diode array detector (DAD, 280, 330, and $370 \mathrm{~nm}$ as the preferred wavelengths) and an ESI mass spectrometer operated in the negative mode (Linear Ion Trap LTQ XL mass spectrometer, Thermo Finnigan, San Jose, CA, USA). Calibration curves were prepared with different available standards and the results are expressed as mg per $\mathrm{g}$ of extract.

\subsection{Antioxidant activity assays}

Four different in vitro methods were used to evaluate the antioxidant activity, DPPH radical-scavenging activity, reducing power, $\beta$-carotene bleaching inhibition assay and lipid peroxidation inhibition by TBARS using methodologies previously described by Sobral et al. ${ }^{28}$ Results are expressed as $\mathrm{EC}_{50}$ values $\left(\mu \mathrm{g} \mathrm{mL} \mathrm{m}^{-1}\right)$ and Trolox was used as a positive control.

\subsection{Anti-inflammatory activity assay}

LPS-induced NO (nitric oxide) production by the murine macrophage (RAW 264.7) cell line was determined using the 
nitrite concentration in the culture medium according to a method previously described by Sobral et $a l^{28}$ Results are expressed as $\mathrm{EC}_{50}$ values $\left(\mu \mathrm{g} \mathrm{mL}^{-1}\right)$, and dexamethasone was used as a positive control.

\subsection{Cytotoxicity assays}

Cytotoxicity was evaluated against four human tumor cell lines, MCF-7 (breast carcinoma), NCI-H460 (non-small cell lung cancer), HeLa (cervical carcinoma), HepG2 (hepatocellular carcinoma), and non-tumor porcine liver cell line (PLP2), using the sulphorhodamine assay previously described by Sobral et al. ${ }^{28}$ Results are expressed as $\mathrm{GI}_{50}\left(\mu \mathrm{g} \mathrm{mL}^{-1}\right)$ and Ellipticine was used as a positive control.

\subsection{Antimicrobial activity assays}

The antimicrobial activity of the samples was tested against a range of strains from different microorganism: four Grampositive bacteria (MRSA - methicillin-resistant Staphylococcus aureus, MSSA - methicillin-susceptible Staphylococcus aureus, Listeria monocytogenes and Enterococcus faecalis) and five Gram-negative bacteria (Escherichia coli, Klebsiella pneumoniae, Proteus mirabilis, Morganella morganii and Pseudomonas aeruginosa) and one yeast (Candida albicans). The minimal inhibitory concentrations (MIC) were performed by the microdilution method using the $p$-iodonitrotetrazolium chloride (INT) colorimetric assay according to Dias et $a l^{29}$ The minimal bactericidal concentration (MBC) and minimal fungicidal concentration (MFC) were calculated by adding $10 \mu \mathrm{L}$ of the MIC value to fresh culture medium to see whether the bacteria were able to grow. After $24 \mathrm{~h}$ of incubation at $37^{\circ} \mathrm{C}, \mathrm{MBC}$ and MFC were registered. The antibiotic susceptibility profile of microorganisms has previously been described. ${ }^{29}$

\subsection{Statistical analysis}

For each species, three samples were used and all the assays were carried out in triplicate. Statistical comparisons were performed using the SPSS Statistics v. 23.0 program (differences were significant at the level of $\alpha=0.05$ ) by using one-way analysis of variance (ANOVA) followed by Tukey's HSD. When necessary, a Student's $t$-test was used to determine the significant differences between less than three different samples, with $p=0.05$. All the data were expressed as the mean values with standard deviations (SD).

\section{Results and discussion}

\subsection{Phenolic compound characterization}

As shown in Tables 1 and 2, a total of thirteen and nine individual phenolic compounds were identified in J. phoenicea and C. cinerea, respectively. Nine flavonols, one biflavone, flavan-3ol, flavone, and a phenolic acid were identified in J. phoenicea; on the other hand, four flavones, two flavonols, and three phenolic acids were identified in C. cinerea.

Regarding J. phoenicea, peaks $2^{\mathrm{JP}}, 6^{\mathrm{JP}}$ and $9^{\mathrm{JP}}$ were positively identified according to their retention time, mass and UV-vis 
characteristics by a comparison with commercial standards. The remaining compounds were tentatively identified based on their pseudomolecular ions and fragmentation pattern. Flavonols were the most abundant flavonoids present in this species, representing $51-57 \%$ of the phenolic composition, with peaks $3^{\mathrm{JP}}, 4^{\mathrm{JP}}, 5^{\mathrm{JP}}, 7^{\mathrm{JP}}$, and $8^{\mathrm{JP}}$ being identified as myricetin glycosides based on their UV spectra $\left(\lambda_{\max }\right.$ around $\left.356 \mathrm{~nm}\right)$ and the production of a $\mathrm{MS}^{2}$ fragment ion at $\mathrm{m} / \mathrm{z} 317$. Similarly, peaks $9^{\mathrm{JP}}, 10^{\mathrm{JP}}$ and $11^{\mathrm{JP}}$ were identified as quercetin ( $\lambda_{\max }$ around $353 \mathrm{~nm}, \mathrm{MS}^{2}$ fragment at $\mathrm{m} / z$ 301) glycosides, and peak 13 as isorhamnetin $\left(\lambda_{\max }\right.$ around $350 \mathrm{~nm}, \mathrm{MS}^{2}$ fragment at $\mathrm{m} / \mathrm{z} 315)$ glycoside. Peak $3^{\mathrm{JP}}\left([\mathrm{M}-\mathrm{H}]^{-}\right.$at $\left.\mathrm{m} / \mathrm{z} 611\right)$ was identified as myricetin-O-pentosyl-O-hexoside, in which the $\mathrm{MS}^{2}$ fragments revealed the alternative loss of pentosyl $(\mathrm{m} / \mathrm{z}$ at $479 ;-132 \mathrm{u})$ and hexosyl $(\mathrm{m} / \mathrm{z}$ at $317 ;-162 \mathrm{u})$ residues, indicating the location of each residue at different positions of the aglycone. The remaining compounds presented $\mathrm{MS}^{2}$ fragments corresponding to distinct losses of dihexosyl $(-324 \mathrm{mu})$, hexosyl (-162 mu), rhamnosyl (-146 mu), and pentosyl $(-132 \mathrm{mu})$ moieties. An elution order coherent with the type of sugar substituent and according to their expected polarity was presented, although the position and nature of the sugar moieties could not be identified, because their retention times did not correspond to any of the standards available. Peak 7 was identified as myricetin-3-O-rhamnoside, which was previously identified in berries and leaves of $J$. phoenicea by Ali et al. ${ }^{15}$ Peak $12\left([\mathrm{M}-\mathrm{H}]^{-}\right.$at $\left.\mathrm{m} / \mathrm{z} 551\right)$ was identified as a methylbiflavonoid taking into account the findings of Innocenti et $a l^{30}$ and Miceli et al. ${ }^{31}$ identifying this compound in fruits of Juniperus communis. Peak $1\left([\mathrm{M}-\mathrm{H}]^{-}\right.$at $\left.\mathrm{m} / \mathrm{z} 337\right)$ was identified as 3-p-coumaroylquinic acid taking into account the hierarchical keys previously reported by Clifford et al. ${ }^{32}$ This was the only phenolic acid present, and accounted for $43-49 \%$ of the total phenolic compounds.

In general, 3-p-coumaroylquinic acid was the main phenolic compound present in $J$. phoenicea, followed by quercetin-Opentoside and myricetin-O-pentoside. Moreover, the hydroethanolic extract presented a higher concentration in these than in the infusion extract.

The obtained individual profile was different from those reported for the Egyptian J. phoenicea berries and leaves' extracts, which revealed the presence of two major biflavonoid compounds; cupressuflavone and amentoflavone in the ethyl acetate fraction, four flavonoids (myricitrin, quercetin, cosmosin, quercitrin), and two phenolic acids ( $p$-coumaric acid and caffeic acid) in the methanol fraction. ${ }^{15}$ The only compound that was similar to the one identified in the present work was myricitrin (peak 7). Moreover, Alqasoumi et al. ${ }^{19}$ studied $J$. phoenicea petroleum ether, chloroform, and methanol fractions from Saudi Arabia, resulting in the identification of five known diterpenoids (13-epicupressic acid, imbricatolic acid, 7- $\alpha$-hydroxysandaracopimaric acid, 3- $\beta$-hydroxysandaracopimaric acid and isopimaric acid) and four flavonoid derivatives (cupressuflavone, hinokiflavone, hypolaetin-7-O- $\beta$-xylopyranoside, and (+)-catechin). Maamoun et $a .^{16}$ identified 4 flavonoids (isoetin-7-O- $\beta$-glucoside, isoscutellarein, amentoflavone, and 
Table 3 Antioxidant activity and NO production inhibition capacity of $J$. phoenicae and C. cinerea extracts (mean \pm SD)

\begin{tabular}{|c|c|c|c|c|c|}
\hline & \multicolumn{2}{|l|}{$J \cdot$ phoenicea } & \multicolumn{2}{|l|}{ C. cinerea } & \multirow[b]{2}{*}{$\begin{array}{l}\text { Positive } \\
\text { control }^{a}\end{array}$} \\
\hline & $\begin{array}{l}\text { Hydroethanolic } \\
\text { extract }\end{array}$ & $\begin{array}{l}\text { Infusion } \\
\text { extract }\end{array}$ & $\begin{array}{l}\text { Hydroethanolic } \\
\text { extract }\end{array}$ & $\begin{array}{l}\text { Infusion } \\
\text { extract }\end{array}$ & \\
\hline \multicolumn{6}{|c|}{ Antioxidant activity $\left(\mathrm{EC}_{50}\right.$ values, $\left.\mu \mathrm{g} \mathrm{mL}^{-1}\right)$} \\
\hline DPPH scavenging activity & $12 \pm 1 d$ & $22.4 \pm 0.6 c$ & $26.0 \pm 0.1 \mathrm{a}$ & $24.8 \pm 0.2 \mathrm{~b}$ & $42 \pm 1$ \\
\hline Reducing power & $12.0 \pm 0.4 \mathrm{~d}$ & $18.2 \pm 0.3 c$ & $31.9 \pm 0.2 b$ & $38 \pm 1 \mathrm{a}$ & $41 \pm 1$ \\
\hline $\begin{array}{l}\beta \text {-Carotene bleaching } \\
\text { inhibition }\end{array}$ & $11.57 \pm 0.08 c$ & $20 \pm 1 \mathrm{a}$ & $14.7 \pm 0.2 b$ & $20.2 \pm 0.8 \mathrm{a}$ & $18 \pm 1$ \\
\hline TBARS inhibition & $7.6 \pm 0.3 \mathrm{a}$ & $6.7 \pm 0.2 b$ & $7.4 \pm 0.3 \mathrm{a}$ & $7.5 \pm 0.2 \mathrm{a}$ & $23 \pm 1$ \\
\hline \multicolumn{6}{|c|}{ Anti-inflammatory activity $\left(\mathrm{EC}_{50}\right.$ values, $\left.\mu \mathrm{g} \mathrm{mL}^{-1}\right)$} \\
\hline Nitric oxide (NO) production & $51 \pm 4 d$ & $70 \pm 5 c$ & $105 \pm 9 b$ & $122 \pm 6 a$ & $16 \pm 1$ \\
\hline
\end{tabular}

agathisflavone) from ethanol, petroleum ether, chloroform, ethyl acetate, and methanol extracts of $J$. phoenicea growing in Egypt. These differences could be attributed to several factors such as geographical location, the part of the plant used and especially the use of different extraction methodologies and solvents.

Concerning $C$. cinerea, phenolic acids were the minor group of compounds present (22-28\%), while flavonoids represented $72-78 \%$ of the phenolic composition. Peaks $1^{\mathrm{cc}}, 6^{\mathrm{cc}}$ and $8^{\mathrm{cc}}$ were identified as 5-O-caffeoylquinic acid, 3,5-O-dicaffeoylquinic acid, and 4,5-O-caffeoylquinic acid, respectively, according to the hierarchical keys previously developed by Clifford et al. ${ }^{32}$ These compounds were also found in the areal parts of Morocco C. cinerea methanol extracts. ${ }^{25}$ The remaining compounds correspond to flavonoid derivatives, mainly luteolin ( $\lambda_{\max }$ around $345 \mathrm{~nm}, \mathrm{MS}^{2}$ fragment at $\mathrm{m} / z$ 285) and quercetin ( $\lambda_{\max }$ around $350 \mathrm{~nm}, \mathrm{MS}^{2}$ fragment at $\mathrm{m} / z$ 301) glycosides. Peaks $2^{\mathrm{cc}}\left([\mathrm{M}-\mathrm{H}]^{-}\right.$at $\left.m / z 609\right), 3^{\mathrm{cc}}\left([\mathrm{M}-\mathrm{H}]^{-}\right.$at $\left.m / z 463\right), 4^{\mathrm{cc}}$ $\left([\mathrm{M}-\mathrm{H}]^{-}\right.$at $\left.m / z 579\right)$, and $5^{\mathrm{cc}}\left([\mathrm{M}-\mathrm{H}]^{-}\right.$at $\left.m / z 447\right)$ were identified as luteolin-dihexoside, quercetin- $O$-hexoside, luteolin-O-pentosyl-hexoside, and luteolin-7-O-glucoside (identified in comparison with a commercial standard), using a similar reasoning as for the compounds described in $J$. phoenicea. Furthermore, peaks $7\left([\mathrm{M}-\mathrm{H}]^{-}\right.$at $\left.m / z 549\right)$ and $9\left([\mathrm{M}-\mathrm{H}]^{-}\right.$at $m / z$ 533) released a MS $^{2}$ fragment at $m / z 301$ and 285 ([M $\mathrm{H}-162-86]^{-}$, loss of a malonylhexoside moiety), being tentatively assigned quercetin and luteolin-O-malonylhexoside, respectively.

Overall, luteolin-7-O-glucoside, luteolin-O-malonylhexoside, and 5-O-caffeoylquinic acid were the main molecules present in both infusion and hydroethanolic extracts obtained from C. cinerea; thus the latter extracts revealed the highest concentration in all the detected compounds.

Dendougui et $a .^{33}$ studied the ethanolic extract of C. cinerea from Algeria, revealing the presence of germacranolide, tatridin A, and seventeen flavonoid derivatives, such as luteolin, apigenin, and quercetin glycosides. Khallouki et al. ${ }^{25}$ studied Morocco C. cinerea methanol extracts, describing the presence of phenolic acids (chlorogenic acid and dicaffeoylquinic acid derivatives) and one flavonoid (luteolin-4'-O-glucoside), thus being very similar to the herein described phenolic acid composition. Ahmed et al. ${ }^{26}$ reported different flavonoids in this species, namely $7-O-\beta$-D-diglucoside and 7-O- $\beta$-D-glucoside of luteolin, and luteolin itself, as well as apigenin-7-O- $\alpha-\mathrm{L}^{-}$ rhamnoside. All of these described profiles present some similarities to the ones presented herein. Thus, the variances in the chemical composition could also be due to the same factors mentioned above for the precedent species, including different types of extraction methodologies, the nature of the solvents used, the bioclimatic zone divergence and the plant parts used to obtain the extracts.

\subsection{Antioxidant activity}

The results on the antioxidant activity of both J. phoenicea and C. cinerea hydroethanolic and infusion extracts are shown in Table 3. For a broader evaluation of the antioxidant capacity, four assays were carried out: DPPH radical scavenging activity, reducing power, $\beta$-carotene bleaching inhibition and lipid peroxidation inhibition in brain cell homogenates (TBARS). The results were compared with the standard Trolox and expressed as $\mathrm{EC}_{50}$ values. Based on these results, J. phoenicea and C. cinerea extracts showed interesting antioxidant properties, particularly for the TBARS assays, in which all samples were demonstrated to be two to three times more effective than Trolox, with $\mathrm{EC}_{50}$ values of $7.6 \pm 0.3$ and $7.4 \pm 0.3 \mu \mathrm{g} \mathrm{mL} \mathrm{m}^{-1}$ for hydroethanolic extracts and $\mathrm{EC}_{50}$ of $6.7 \pm 0.2$ and $7.5 \pm 0.2$ $\mu \mathrm{g} \mathrm{mL}^{-1}$ for infusion extracts of $J$. phoenicea and C. cinerea, respectively. These extracts showed anti-lipid peroxidation proprieties, which are of great interest in food preservation. ${ }^{11}$ The scavenging activity evaluated by the DPPH assay showed that J. phoenicea presented very low $\mathrm{EC}_{50}$ values for both extracts $\left(12 \pm 1\right.$ and $22.4 \pm 0.6 \mu \mathrm{g} \mathrm{mL}{ }^{-1}$ for hydroethanolic and infusion extracts, respectively), indicating a strong ability to donate hydrogen and scavenge the free $\mathrm{DPPH}$ radical, probably due to 
its phenolic composition. The results obtained were higher than the ones reported by El Jemli et al. ${ }^{34}$ and Keskes et al., ${ }^{14}$ who evaluated the ability of a Morrocan J. phoenicea water extract for the scavenging activity of $\mathrm{DPPH}\left(\mathrm{EC}_{50}=30.7 \pm\right.$ $0.1 \mu \mathrm{g} \mathrm{mL}^{-1}$ ), and also Tunisien $J$. phoenicea ethyl acetate extract $\left(\mathrm{EC}_{50}=220 \mu \mathrm{g} \mathrm{mL} \mathrm{m}^{-1}\right)$ and hexane extract, which did not show activity using this method. Nevertheless, Keskes et al. ${ }^{14}$ reported the methanol extract to show a stronger ability to scavenge DPPH radicals $\left(\mathrm{EC}_{50}\right.$ value $\left.=2 \mu \mathrm{g} \mathrm{mL}^{-1}\right)$. Taviano et al. ${ }^{35}$ studied the antioxidant activity of methanol and water extracts of five different Turkish Juniperus species, which showed a weaker activity in comparison with the herein studied extracts. On the other hand, the $C$. cinerea infusion extract demonstrated a higher $\mathrm{DPPH}$ radical scavenging activity $\left(\mathrm{EC}_{50}=\right.$ $24.8 \pm 0.2 \mu \mathrm{g} \mathrm{mL} \mathrm{m}^{-1}$ ) in comparison with its hydroethanolic extract $\left(\mathrm{EC}_{50}=26.0 \pm 0.1 \mu \mathrm{g} \mathrm{mL} \mathrm{mL}^{-1}\right)$, contrary to what happened for all the remaining methods for both species. Moreover, the activities of all the samples were higher than the ones displayed by the commercial standard Trolox $\left(\mathrm{EC}_{50}=42 \pm 1 \mu \mathrm{g} \mathrm{mL} \mathrm{m}^{-1}\right)$. These data are in accordance with the results obtained by Khallouki et al., ${ }^{25}$ who also reported a strong antioxidant capacity (DPPH and FRAP assays) of the methanol extract from Moroccan $C$. cinerea, and correlated this activity with its significant content in echinoids and flavonoids. In fact, both extracts from the two plant species revealed a relevant reducing power, which increased with the increase of the extract concentration, ranging from $12.04 \pm 0.4$ to $38.1 \pm 1 \mu \mathrm{g} \mathrm{mL}^{-1}$, being more effective than Trolox $\left(41 \pm 1 \mu \mathrm{g} \mathrm{mL}^{-1}\right)$. Once more, $J$. phoenicea hydroethanolic and infusion extracts exhibited the best ability to reduce $\mathrm{Fe}^{3+}$ to $\mathrm{Fe}^{2+}$ (Table 3). The susceptibility of an antioxidant capable of neutralizing free radicals and inhibiting lipid peroxidation can be evaluated through a $\beta$-carotene bleaching inhibition assay. For this methodology, the hydroethanolic extracts of $J$. phoenicea and $C$. cinerea demonstrated the highest activity $\left(\mathrm{EC}_{50}\right.$ values of $11.57 \pm 0.08$ and $14.7 \pm 0.2 \mu \mathrm{g} \mathrm{mL} \mathrm{m}^{-1}$, respectively), revealing a higher activity than Trolox $\left(\mathrm{EC}_{50}\right.$ values $\left.=18.0 \pm 1 \mu \mathrm{g} \mathrm{mL}^{-1}\right)$, while the infusion extract of both plants showed lower or closer activity in comparison with the commercial standard. The effectiveness of the hydroethanolic extracts can be explained by their higher concentration in phenolic compounds, which could influence their capacity to scavenge free radicals and prevent lipid peroxidation. $^{36}$

\subsection{Anti-inflammatory activity}

The anti-inflammatory effect was evaluated using murine macrophage-like RAW 264.7 cells and quantified through the nitric oxide (NO) production, and the results are summarized in Table 3. All the samples revealed inhibition of NO production with $\mathrm{EC}_{50}$ values ranging between $51 \pm 4$ and $122 \pm$ $6 \mu \mathrm{g} \mathrm{mL}^{-1}$. It can be noticed that the highest activity was shown by both extracts of $J$. phoenicea (hydroethanolic and infusion, with $\mathrm{EC}_{50}$ values of $51 \pm 4$ and $70 \pm 5 \mu \mathrm{g} \mathrm{mL} \mathrm{m}^{-1}$, respectively). This activity could be attributed to the high content of 3-p-coumaroylquinic acid and the flavonol derivatives found in this species. The obtained results are also in agreement with those reported by Jeong et al., ${ }^{37}$ who found a powerful anti-inflammatory activity in a Korean Juniper rigida methanolic extract and its fractions ( $n$-hexane, chloroform, ethyl acetate and $n$-butanol). This ability was attributed to the phenolic composition present in the extract, especially the presence of phenylpropanoid glycosides, with $p$-hydroxy groups, massoniaside A, (+)-catechin, and amentoflavone, which effectively inhibited LPS-induced NO production in RAW264.7 cells. $^{37}$ Otherwise, C. cinerea hydroethanolic and infusion extracts revealed lower inhibition of NO production, with $\mathrm{EC}_{50}$ values of $105 \pm 9$ and $122 \pm 6 \mu \mathrm{g} \mathrm{mL} \mathrm{m}^{-1}$, respectively. The activity observed for both extracts of $C$. cinerea could be attributed to the presence of phenolic compounds, such as luteolin-7-O-glucoside, luteolin- $O$-malonylhexoside, and 5-Ocaffeoylquinic acid. These findings could be associated with the important usage of this species in traditional African medicine. ${ }^{25,33}$ To the best of our knowledge, this is the first report on the anti-inflammatory potential of $J$. phoenicea leaves and C. cinerea areal parts.

\subsection{Cytotoxic effects}

The results on the antiproliferative effects of $J$. phoenicea and C. cinerea hydroethanolic and infusion extracts are summarized in Table 4. All the tested samples presented significant

Table 4 Cytotoxic properties of J. phoenicae and C. cinerea extracts in human tumor cell lines and non-tumor liver primary cells (mean \pm SD)

\begin{tabular}{|c|c|c|c|c|c|}
\hline & \multicolumn{2}{|l|}{ J. phoenicae } & \multicolumn{2}{|l|}{ C. cinerea } & \multirow[b]{2}{*}{ Ellipticine } \\
\hline & $\begin{array}{l}\text { Hydroethanolic } \\
\text { extract }\end{array}$ & $\begin{array}{l}\text { Infusion } \\
\text { extract }\end{array}$ & $\begin{array}{l}\text { Hydroethanolic } \\
\text { extract }\end{array}$ & $\begin{array}{l}\text { Infusion } \\
\text { extract }\end{array}$ & \\
\hline \multicolumn{6}{|c|}{ Human tumor cell lines ( $\mathrm{GI}_{50}$ values, $\mu \mathrm{g} \mathrm{mL}^{-1}$ ) } \\
\hline MCF-7 (breast carcinoma) & $11 \pm 1 d$ & $19 \pm 1 \mathrm{c}$ & $53 \pm 4 b$ & $77 \pm 6 \mathrm{a}$ & $0.91 \pm 0.04$ \\
\hline NCI-H460 (non-small cell lung cancer) & $30 \pm 1 \mathrm{c}$ & $51 \pm 3 b$ & $50 \pm 3 b$ & $101 \pm 10 \mathrm{a}$ & $1.03 \pm 0.09$ \\
\hline HeLa (cervical carcinoma) & $9 \pm 1 d$ & $17 \pm 2 \mathrm{c}$ & $47 \pm 5 b$ & $51 \pm 4 \mathrm{a}$ & $1.91 \pm 0.06$ \\
\hline HepG2 (hepatocellular carcinoma) & $15 \pm 1 d$ & $22.4 \pm 0.7 \mathrm{c}$ & $31 \pm 2 b$ & $42 \pm 4 a$ & $1.1 \pm 0.2$ \\
\hline \multicolumn{6}{|l|}{ Non-tumor cells ( $\left(\mathrm{GI}_{50}\right.$ values, $\left.\mu \mathrm{g} \mathrm{mL}^{-1}\right)$} \\
\hline PLP2 (porcine liver primary cells) & $88 \pm 8 d$ & $137 \pm 12 b$ & $120 \pm 8 c$ & $198 \pm 5 a$ & $3.2 \pm 0.7$ \\
\hline
\end{tabular}

$\mathrm{GI}_{50}$ values (mean $\pm \mathrm{SD}$ ) correspond to the sample concentration achieving 50\% of growth inhibition in human tumor cell lines or in liver primary culture PLP2. In each row different letters mean significant differences between extracts $(p<0.05)$. 
cytotoxic properties for the four human tumor cell lines tested (MCF-7, NCI-H460, HeLa and HepG2), with GI $_{50}$ values ranging from $9 \pm 1$ to $101 \pm 10 \mu \mathrm{g} \mathrm{mL}{ }^{-1}$. Furthermore, the samples also presented cytotoxic effects against non-tumor cells (PLP2 - porcine liver primary cells); thus the $\mathrm{GI}_{50}$ values were much higher than those needed to exert antiproliferative activity in tumor cells and also much higher than those exhibited by the standard Ellipticine. J. phoenicea hydroethanolic and infusion extracts demonstrated a higher cytotoxic potential in comparison with $C$. cinerea. The obtained results are also in agreement with those reported by Maamoun et al., ${ }^{16}$ who found higher activity against lung carcinoma (H460), liver tumor (HepG2), and breast carcinoma (MCF7) cell lines with the crude extract of Egyptian J. phoenicea leaves. Consecutively, these authors screened the flavonoid agathisflavone, which recorded higher cytotoxicity in the lung carcinoma (H460). ${ }^{16}$ Additionally, a significant in vivo hepatoprotective effect was reported for J. phoenicea leaves. ${ }^{15,38}$ Tavares et al. ${ }^{39}$ also proved the neuroprotective potential of the phenolic fractions obtained from Portuguese J. phoenicea and other species of Juniperus, attributing this capacity to the biflavones detected, especially to amentoflavone. Furthermore, J. phoenicea is well known to contain lignans, which are recognized for their interesting antiproliferative and antiviral activities. ${ }^{40}$ Many reports supposed that Juniperus species could be a source of bioactive compounds with potential anti-cancer effects. ${ }^{41}$

On the other hand, C. cinerea hydroethanolic and infusion extracts also presented antiproliferative activity, being more active in the following order: HepG2 $(31 \pm 2$ and $42 \pm 4$ $\left.\mu \mathrm{g} \mathrm{mL}^{-1}\right)$, HeLa $\left(47 \pm 5\right.$ and $\left.51 \pm 4 \mu \mathrm{g} \mathrm{mL}^{-1}\right)$, NCI-H460 $(50 \pm 3$ and $101 \pm 10 \mu \mathrm{g} \mathrm{mL}{ }^{-1}$ ) and MCF-7 (53 \pm 4 and $\left.77 \pm 6 \mu \mathrm{g} \mathrm{mL}^{-1}\right)$. In fact, the cytotoxicity of $C$. cinerea extracts was lower than the one observed for $J$. phoenicea hydroethanolic and infusion extracts; these differences could be due to the distinct individual phenolic profiles of both extracts. It has been previously highlighted that some phenolic compounds can contribute to protection against cancer disease, for example, $p$-coumaroylquinic acid, quercetin, and myricetin derivatives, which were the major phenolic compounds found in J. phoenica. These compounds have exhibited a protective role for in vivo hepatotoxicity and nephrotoxicity. ${ }^{15}$ To the best of our knowledge there are no previous reports on the cytotoxic activity of C. cinerea.

\subsection{Antimicrobial activity}

The antimicrobial activity results of both $J$. phoenicea and C. cinerea extracts (hydroethanolic and infusion) tested against ten pathogenic strains, and expressed as the minimal inhibitory concentrations (MIC), minimal bactericidal concentrations (MBC) and minimal fungicidal concentrations (MFC), are presented in Table 5. Overall, the extracts obtained from both species were found to have moderate to weak activity, with a higher effectiveness towards Gram-positive bacteria, in comparison with Gram-negative. MIC values ranged between 5 and $20 \mathrm{mg} \mathrm{mL}{ }^{-1}$, and the inhibitory effect tested against all the bacterial strains was more bacteriostatic than bactericidal.

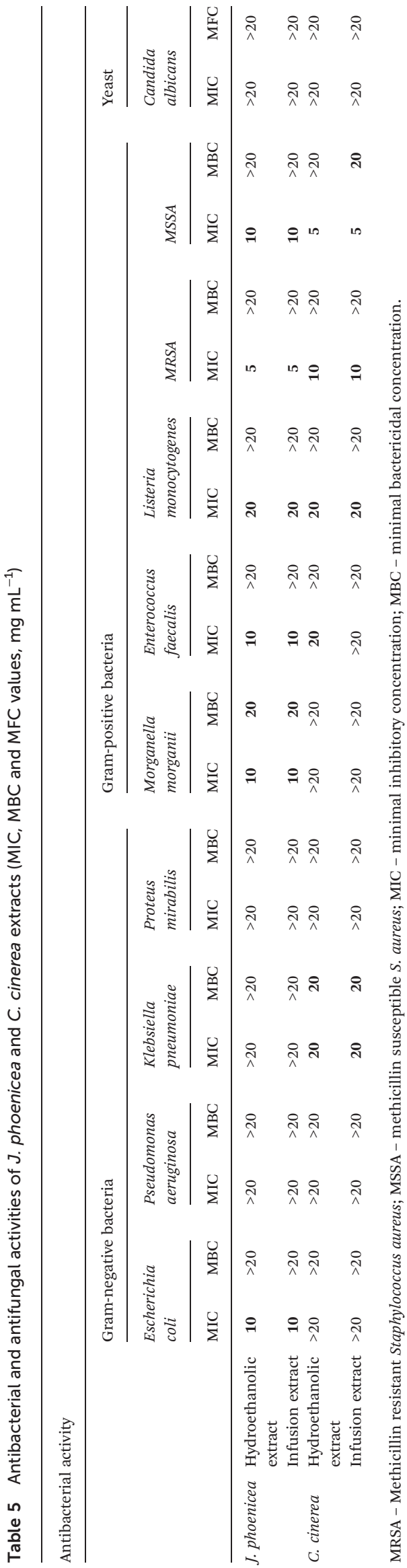


The strains MRSA and MSSA were demonstrated to be more susceptible to both $J$. phoenicea (MIC $=5$ and $10 \mathrm{mg} \mathrm{mL} \mathrm{m}^{-1}$, respectively) and $C$. cinerea (MIC $=10$ and $5 \mathrm{mg} \mathrm{mL}^{-1}$, respectively) extracts. On the other hand, Morganella morganii also showed susceptibility towards $J$. phoenicea extracts revealing MICs and MBCs values of 10 and $20 \mathrm{mg} \mathrm{mL}^{-1}$, respectively. Regarding Gram-negative bacteria, J. phoenicea and C. cinerea only presented inhibitory activity for Escherichia coli $(\mathrm{MIC}=$ $10 \mathrm{mg} \mathrm{mL}^{-1}$ ) and Klebsiella pneumonia (MIC and $\mathrm{MBC}=20$ $\mathrm{mg} \mathrm{mL} \mathrm{m}^{-1}$ ). It is important to highlight that both $J$. phoenicea extracts had the same behavior on all the bacteria tested, while C. cinerea presented variation in the used extracts, especially for the strains E. faecalis and MSSA. Regarding the yeast Candida albicans, the extracts did not express any activity up to the maximal tested concentration.

The antimicrobial activity of the $J$. phoenicea extract is supported by studies performed by Hammami et al., ${ }^{42}$ who demonstrated moderate to good activity of a Tunisian $J$. phoenicea aqueous extract, obtained from seeds, and its fractions (methanol and acetone), against Gram-positive (Listeria monocytogenes, Listeria innocua, and Listeria ivanovii) and Gram-negative (Escherichia coli and Pseudomonas aeruginosa) bacteria. In a similar order, Alzand et $a l .{ }^{43}$ proved significant growth inhibition of Escherichia coli, Staphylococcus aureus, and Klebsiella pneumonia using alcoholic extracts of J. phoenicea barks from India. In contrast, Miceli et al. ${ }^{31}$ described the antibacterial activity of different species of Turkish Juniperus (J. communis L. var. communis and J. communis L. var. saxatilis. Pall) methanol extracts, which showed moderate capacity only against Gram-positive bacteria. It should also be highlighted that the part of the plant used and the phenolic compound concentration will also have a great influence on the antibacterial activity obtained for each extract. Thus, the antimicrobial activity obtained for both extracts of $J$. phoenicea could also be related to the presence of phenolic compounds, such as quercetin derivatives and $p$-coumaroylquinic acid, which are recognized for their antimicrobial actions, ${ }^{4,44}$ supporting the antibacterial effectiveness of the studied species.

Concerning $C$. cinerea antibacterial activity, it is in agreement with the results described by Bensizerara et al. ${ }^{23}$ who evaluated the antibacterial properties of extracts obtained from C. cinerea aerial parts using different polarity solvents (ethanol, $n$-butanol, ethyl acetate and petroleum ether). These authors revealed weak activity for all the mentioned extracts; thus the most active fraction was $n$-butanol. Additionally, Markouk et $a .^{22}$ reported that the $n$-butanol extract obtained from the Moroccan $C$. cinerea was highly effective against germs in the tested concentrations (ranging from 12 to $200 \mu \mathrm{g} \mathrm{mL} \mathrm{mL}^{-1}$ ). Nevertheless, the inhibition ability of the bacterial growth shown by $C$. cinerea could also be associated with important levels of flavonoids, such as quercetin and luteolin derivatives, as was reported by Dendougui et $a l^{33}$ and Ahmed et al. ${ }^{26}$

Overall, the wide range of bioactive properties (antioxidant, anti-inflammatory, cytotoxic and antibacterial) shown by the hydroethanolic and infusion extracts of the studied Saharan plants supports their traditional use as a popular remedy in the treatment of cancer, infectious and inflammatory diseases. These properties may be related to the presence of different phenolic compounds at variable contents. Thus, further studies are needed to establish the mechanisms of action, supporting the use of these plants in the pharmaceutical and food fields.

\section{Conflicts of interest}

No conflict of interest.

\section{Acknowledgements}

The authors are grateful to the Foundation for Science and Technology (FCT, Portugal) and FEDER under Program PT2020 for financial support to CIMO (UID/AGR/00690/2013) through L. Barros and R. Calhelha contracts. The authors are also grateful to the FEDER-Interreg España-Portugal programme for financial support through the project 0377_Iberphenol_6_E.

\section{References}

1 M. Saxena, J. Saxena, R. Nema, D. Singh and A. Gupta, Med. Plants Cent. Asia Uzb. Kyrg, 2013, vol. 1, pp. 13-14.

2 C.-C. Xu, B. Wang, Y.-Q. Pu, J.-S. Tao and T. Zhang, Chin. J. Nat. Med., 2017, 15, 721-731.

3 J. J. Cui, J. F. Yuan and Z. Q. Zhang, J. Ethnopharmacol., 2010, 132, 512-517.

4 R. Gyawali and S. A. Ibrahim, Food Control, 2014, 46, 412-429.

5 B. E. C. Ziani, L. Barros, A. Z. Boumehira, K. Bachari, S. A. Heleno, M. J. Alves and I. C. F. R. Ferreira, Food Funct., 2018, 9, 149-159.

6 N. Martins, L. Barros, M. Henriques, S. Silva and I. C. F. R. Ferreira, Biomed Res. Int., 2015, 2015, 247382.

7 M. Carocho and I. C. F. R. Ferreira, Anti-Cancer Agents Med. Chem., 2013, 13, 1236-1258.

8 Y. Guo, K. Sakulnarmrat and I. Konczak, Toxicol. Rep., 2014, 1, 385-390.

9 W. Rached, F. Z. Zeghada, M. Bennaceur, L. Barros, R. C. Calhelha, S. Heleno, M. J. Alves, A. M. Carvalho, A. Marouf and I. C. F. R. Ferreira, Ind. Crops Prod., 2018, 112, 460-466.

10 R. Farhoosh, S. Johnny, M. Asnaashari, N. Molaahmadibahraseman and A. Sharif, Food Chem., 2016, 194, 128-134.

11 S. Takwa, C. Caleja, J. C. M. Barreira, M. Soković, L. Achour, L. Barros and I. C. F. R. Ferreira, LWT - Food Sci. Technol., 2018, 88, 47-55.

12 P. Quezel and S. Santa, Nouvelle flore de l'Algérie et des régions désertiques méridionales, Paris, 1963.

13 H. Allali, H. Benmehdi, M. A. Dib, B. Tabti, S. Ghalem and N. Benabadji, Asian J. Chem., 2008, 20, 2701-2710. 
14 H. Keskes, K. Mnafgui, K. Hamden, M. Damak, A. El Feki and N. Allouche, Asian Pac. J. Trop. Biomed., 2014, 4, 649-S655.

15 S. A. Ali, M. Z. Rizk, N. A. Ibrahim, M. S. Abdallah, H. M. Sharara and M. M. Moustafa, World J. Gastrointest. Pharmacol. Ther., 2010, 1, 123-131.

16 M. A. I. Maamoun, S. A. El-sawi, H. M. Motawae, M. A. Sleem, A.-R. O. El-Shabrawy, H. W. Usama and A. A. Farghaly, Mintage J. Pharm. Med. Sci., 2016, 5, 3-9.

17 B. Boulanouar, A. Gherib, S. Aazza, C. Gago and M. M. Grac, Ind. Crops Prod., 2013, 46, 85-96.

18 M. F. Taviano, A. Marino, A. Trovato, V. Bellinghieri, A. Melchini, P. Dugo, F. Cacciola, P. Donato, L. Mondello, A. Güvenç, R. De Pasquale and N. Miceli, Food Chem. Toxicol., 2013, 58, 22-29.

19 S. I. Alqasoumi, A. I. Farraj and M. S. Abdel-Kader, Pak. J. Pharm. Sci., 2013, 26, 999-1008.

20 L. El Rhaffari and A. Zaid, From the sources of knowledge to the medicines of the future, 2002, pp. 293-318.

21 M. Markouk, H. B. Lazrek and M. Jana, Phytother. Res., 1999, 13, 229-230.

22 M. Markouk, A. Redwane, H. B. Lazrek, M. Jana and A. Benjama, Fitoterapia, 1999, 70, 314-316.

23 D. Bensizerara, T. Menasria, M. Melouka, L. Cheriet and H. Chenchouni, Asian Pac. J. Trop. Biomed., 2012, 1-5.

24 N. Belyagoubi-Benhammou, L. Belyagoubi and F. A. Bekkara, J. Med. Plants Res., 2014, 8, 1198-1207.

25 F. Khallouki, K. Sellam, R. Koyun, I. Ricarte, C. Alem, L. Elrhaffari and R. W. Owen, Rec. Nat. Prod., 2015, 9, 572575.

26 A. A. Ahmed, N. H. El-Sayed, S. I. El-Negoum and T. J. Mabry, J. Nat. Prod., 1987, 50, 519-520.

27 S. M. F. Bessada, J. C. M. Barreira, L. Barros, I. C. F. R. Ferreira and M. B. P. P. Oliveira, Ind. Crops Prod., 2016, 89, 45-51.

28 F. Sobral, A. Sampaio, S. Falcão, M. J. R. P. Queiroz, R. C. Calhelha, M. Vilas-Boas and I. C. F. R. Ferreira, Food Chem. Toxicol., 2016, 94, 172-177.

29 M. I. Dias, L. Barros, P. Morales, M. Cámara, M. J. Alves, M. B. P. P. Oliveira, C. Santos-Buelga and I. C. F. R. Ferreira, Food Funct., 2016, 7, 4523-4532.
30 M. Innocenti, M. Michelozzi, C. Giaccherini, F. Ieri, F. F. Vincieri and N. Mulinacci, J. Agric. Food Chem., 2007, 55, 6596-6602.

31 N. Miceli, A. Trovato, P. Dugo, F. Cacciola, P. Donato, A. Marino, V. Bellinghieri, T. M. La Barbera, A. Gljvenç and M. F. Taviano, J. Agric. Food Chem., 2009, 57, 65706577.

32 M. N. Clifford, K. L. Johnston, S. Knight and N. Kuhnert, J. Agric. Food Chem., 2003, 51, 2900-2911.

33 H. Dendougui, S. Seghir, M. Jay, F. Benayache and S. Benayache, Int. J. Med. Aromat. Plants, 2012, 2, 589-595.

34 M. El Jemli, R. Kamal, I. Marmouzi, A. Zerrouki, Y. Cherrah and K. Alaoui, Adv. Pharmacol. Sci., 2016, 2016, 6392656.

35 M. F. Taviano, A. Marino, A. Trovato, V. Bellinghieri, T. M. La Barbera, A. Gvenç, M. M. Hrkul, R. De Pasquale and N. Miceli, Pharm. Biol., 2011, 49, 1014-1022.

36 C. Gardi, K. Bauerova, B. Stringa, V. Kuncirova, L. Slovak, S. Ponist, F. Drafi, L. Bezakova, I. Tedesco, A. Acquaviva, S. Bilotto and G. L. Russo, Arch. Biochem. Biophys., 2015, 583, 150-157.

37 E. J. Jeong, H. Seo, H. Yang, J. Kim, S. H. Sung and Y. C. Kim, J. Enzyme Inhib. Med. Chem., 2012, 27, 875879.

38 A. Laouar, F. Klibet, E. Bourogaa, A. Benamara, A. Boumendjel, A. Chefrour and M. Messarah, Asian Pac. J. Trop. Med., 2017, 10, 263-269.

39 L. Tavares, G. J. McDougall, S. Fortalezas, D. Stewart, R. B. Ferreira and C. N. Santos, Food Chem., 2012, 135, 562-570.

40 G. Comte, D. P. Allais, A. J. Chulia, J. Vercauteren and C. Delage, Phytochemistry, 1996, 41, 1329-1332.

41 A. S. Yaglioglu and F. Eser, S. Afr. J. Bot., 2017, 113, 29-33.

42 R. Hammami, A. Zouhir, J. Ben Hamida, M. Neffati, G. Vergoten, K. Naghmouchi and I. Fliss, Pharm. Biol., 2009, 47, 452-457.

43 K. I. Alzand, D. M. Aziz and M. Tailang, World J. Pharm. Res., 2014, 3, 951-965.

44 Y. Wu, J. Bai, X. Liu, L. Liu, K. Zhong, Y. Huang and H. Gao, RSC Adv., 2018, 8, 4969-4975. 